\title{
miR-124 participates in the proliferation and differentiation of brain glioma stem cells through regulating Nogo/NgR expression
}

\author{
YUN MENG ${ }^{1}$, FURONG SHANG $^{1}$ and YANLIANG ZHU ${ }^{2}$ \\ Departments of ${ }^{1}$ Neurology and ${ }^{2}$ Oncology, Xiangyang Central Hospital, \\ Affiliated Hospital of Hubei University of Art and Science, Xiangyang, Hubei 441021, P.R. China
}

Received December 19, 2018; Accepted May 30, 2019

DOI: $10.3892 /$ etm.2019.7914

\begin{abstract}
The effect of miR-124 on the proliferation and differentiation of brain glioma stem cells and $\mathrm{Nogo} / \mathrm{NgR}$ signaling pathway were investigated. miR-124 mimic, miR-124 inhibitor and miR-control expression vector were designed and produced to transfect U87 glioma stem cells. The results of transfection were tested via RT-qPCR and the expression of protein was detected by western blot analysis. Cell proliferation was detected by MTT proliferation and the proportion of $\mathrm{CD}_{133}{ }^{+}$cells was detected by immunomagnetic beads to determine cell differentiation. The correlation between miR-124 and Nogo-A, and NgR protein expression was analyzed by Spearman correlation analysis. The relative expression of miR-124 in cells of miR-124 mimic group was significantly higher than that of miR-124 inhibitor and miR-control groups $(\mathrm{P}<0.05)$. The relative expression of Nogo-A and $\mathrm{NgR}$ protein in cells of the miR-124 mimic group was significantly lower than that of miR-124 inhibitor and miR-control groups $(\mathrm{P}<0.05)$. Absorbance values of the cells in the miR-124 mimic and miR-control groups were significantly lower than those in the miR-124 inhibitor group at each time point $(\mathrm{P}<0.05)$, while the values of the cells in the miR-124 mimic group were significantly lower than that in miR-control group $(\mathrm{P}<0.05)$. The level of CD133 ${ }^{+}$cells in miR-124 mimic group was significantly lower than that in miR-124 inhibitor and miR-control groups $(\mathrm{P}<0.05)$, while the level of CD133 ${ }^{+}$cells in miR-124 inhibitor group was higher than that in miR-control group $(\mathrm{P}<0.05)$. Correlation analysis revealed that there was a negative correlation between miR-124 and the expression of Nogo-A and NgR protein $(\mathrm{P}<0.05)$. miR-124 may participate in the differentiation of brain glioma stem cells through the Nogo/NgR pathway, which may bring a new direction for the clinical treatment of brain glioma.
\end{abstract}

Correspondence to: Dr Yanliang Zhu, Department of Oncology, Xiangyang Central Hospital, Affiliated Hospital of Hubei University of Art and Science, 139 Jingzhou Street, Xiangyang, Hubei 441021, P.R. China

E-mail: my5201718@sina.com

Key words: miR-124, Nogo, NgR, brain glioma stem cells, proliferation, differentiation

\section{Introduction}

Brain glioma is the most common primary malignant tumor of intracranial tumors, accounting for approximately $45 \%$ of all intracranial tumors. The prognosis of brain glioma patients is generally poor, and with the increase of malignancy, the prognosis is worse $(1,2)$. Findings have shown that the median survival time of patients with grade IV glioblastoma multiform is only 1 year, and the 5-year survival rate is less than $5 \%$, being one of the malignant tumors with the highest human mortality (3). Surgical treatment is the most effective treatment for brain gliomas. With the development of molecular-targeted therapy, the survival of brain glioma patients has been improved effectively, but the overall therapeutic effect is still not ideal and the occurrence and development mechanism of brain glioma is not clear yet $(4,5)$. Therefore, it is very important to continue to study the changes of molecular level in brain gliomas and to find new therapeutic targets for the clinical treatment of gliomas.

In 2008, it was reported that miR-124 could inhibit the proliferation of glioblastoma multiform by affecting CDK6 to promote the differentiation of brain glioma stem cells (6). However, little further research has been carried out on this issue. Thus, the mechanism of miR-124 regulating brain glioma stem cell differentiation is not fully understood, and its role has not been further verified. The Nogo family has three subtypes, Nogo-A, Nogo-B and Nogo-C, which can inhibit the growth and reconnection of synapses in central nervous system (CNS) diseases. Nogo-A is the longest isomer, enriched in CNS, while $\mathrm{NgR}$ is the receptor of Nogo (7). Nogo/ $\mathrm{NgR}$ signaling pathway has been reported to be related to brain injury, and the inhibition of its activation can reduce the death of microglial cells (8). Effect of miR-124 on the proliferation and differentiation of U87 glioma stem cells and its effect on Nogo/NgR signaling pathway were analyzed in this study to explore its mechanism of action.

\section{Materials and methods}

Cell sources. Brain glioma cell U87 MG-Luc2 was purchased from ATCC (ATCCHTB-14-LUC2), hereinafter referred to as U87 cells and has been authenticated by STR profiling (Beijing Microread Genetics Co., Ltd.). The cells were cultured in DMEM complete medium containing $10 \%$ fetal calf serum 
(Shanghai Zhong Qiao Xin Zhou Biotechnology Co., Ltd.) with a culture condition of $37^{\circ} \mathrm{C}, 5 \% \mathrm{CO}_{2}$ and $95 \%$ relative humidity.

This study was approved by the Ethics Committee of Xiangyang Central Hospital, Affiliated Hospital of Hubei University of Art and Science (Xiangyang, China).

Cell passage. When cell attachment growth density of U87 reached $90 \%$, the cells were digested with $0.25 \%$ trypsin. U87 cells were transferred into DMEM medium and cultured in incubators at $37^{\circ} \mathrm{C}, 5 \% \mathrm{CO}_{2}$ then synaptic retraction was observed under a microscope. The culture was collected for the third generation use.

Isolation of U87 brain glioma stem cells. U87 cells with an attachment growth density of $90 \%$ were collected and digested with $0.25 \%$ trypsin. The U87 brain glioma stem cells were sorted by adding tumor stem cell culture medium (Jiangsu Promocell Biotechnology Co., Ltd.). The medium was replaced every two days, centrifugation was performed at $800 \mathrm{x}$ g for $5 \mathrm{~min}$ at $4^{\circ} \mathrm{C}$ before replacement, and then half of the medium was replaced. After 3 weeks, the suspension cells were collected and passaged in accordance with the above method.

Construction and transfection of miR-124 expression vector. The miR-124 mimic, miR-124 inhibitor and miR-control expression vectors were designed and produced by Shanghai Gene Pharmaceutical Technology Co., Ltd. The cells were digested by trypsin for $24 \mathrm{~h}$ before transfection, and U87 stem cells were transfected when the cells were fused to approximately $80 \%$, the specific steps referred to the specification of the kit. The cells were cultured in $37^{\circ} \mathrm{C}, 5 \% \mathrm{CO}_{2}$ incubator for $48 \mathrm{~h}$, and the medium was changed every $6 \mathrm{~h}$. The transfection results were detected by RT-qPCR. Lipofectamine ${ }^{\mathrm{TM}} 2000$ transfection kit was purchased from Shanghai Yanjin Biotechnology Co., Ltd.

$R T-q P C R$. The concentration of cell suspension was adjusted to $1 \times 10^{7}$, and the total RNA was extracted by adding suspension and TRIzol lysate at 3:1. After extraction, $1.5 \%$ agarose gel electrophoresis was used to analyze the integrity of RNA, micro-amount of nucleic acid analyzer was used to detect the purity of extracted RNA. A260/A280 value between 1.8 and 2.0 was considered to meet the experimental requirements. RT-qPCR reaction was performed after the completion of RNA extraction. Reverse transcription system: oligo dt primer 1.0 $\mu \mathrm{l}, 5 \mathrm{X}$ PrimeScript Buffer $4.0 \mu \mathrm{l}, 2.5 \mathrm{U} / \mu \mathrm{l}$ polyA polymerase $1 \mu \mathrm{l}$, dNTP mixture $1.0 \mu \mathrm{l}$, total RNA $2 \mu \mathrm{g}$, RNase-free distilled water was added to $10 \mu 1$. Reaction condition was: $40^{\circ} \mathrm{C}$ for $15 \mathrm{~min}, 85^{\circ} \mathrm{C}$ for $5 \mathrm{sec}$; PCR amplification was carried out after the completion of reverse transcription reaction. PCR amplification system was: cDNA template $2 \mu \mathrm{l}$, SYBR-Green Mix $25 \mu \mathrm{l}$, upstream primer $0.5 \mu \mathrm{l}$, downstream primer $0.5 \mu 1$, double-steamed water was added to $50 \mu \mathrm{l}$. PCR reaction program was: 30 cycles of predenaturation at $95^{\circ} \mathrm{C}$ for $3 \mathrm{~min}$, denaturation at $95^{\circ} \mathrm{C}$ for $30 \mathrm{sec}$, annealing at $55^{\circ} \mathrm{C}$ for $30 \mathrm{sec}$, elongation at $72^{\circ} \mathrm{C}$ for $60 \mathrm{sec}$, elongation at $72^{\circ} \mathrm{C}$ for $5 \mathrm{~min}$ after the cycle was complete. $G A P D H$ was used as the internal parameter of the reaction. Samples were set in triplicate for each test, and $2^{-\mathrm{ACq}}$ was used to analyze the results (9).
The primer sequence was designed and produced by Hepeng (Shanghai) Biotechnology Co., Ltd. (Table I).

Western blot analysis. The expression of Nogo-A and $\mathrm{NgR}$ protein was detected by western blot analysis. The total protein was extracted from the cell by RIPA total protein lysate (Wuhan Aspen Biological Company) and the concentration of extracted protein was determined by $\mathrm{BCA}$, and the BCA protein quantitative detection kit was purchased from Beyotime Institute of Biotechnology. Then, $40 \mu \mathrm{g}$ extracted protein solution was used for SDS-PAGE electrophoresis, and buffer was added at a 1:4 dilution. $\beta$-actin protein was used as an internal reference, the concentration gel electrophoresis was performed at a constant $80 \mathrm{~V}$ for $40 \mathrm{~min}$, and separation gel electrophoresis was performed at a constant $120 \mathrm{~V}$ for $90 \mathrm{~min}$. Trans-membrane was conducted at a constant $100 \mathrm{~V}$ for $100 \mathrm{~min}$ and blocked at $37^{\circ} \mathrm{C}$ for $60 \mathrm{~min}$ after the completion of electrophoresis. After trans-membrane, the immunological reaction was carried out. Incubation was performed with primary rabbit anti-human Nogo-A polyclonal antibody (1:200; cat. no. 10740-1-AP; ProteinTech Group, Inc.) at $4^{\circ} \mathrm{C}$ for $16 \mathrm{~h}$. It was washed the next day in lukewarm water 3 times, 10 min each time with PBS. Then, incubation was performed with secondary goat anti-rabbit polyclonal IgG (1:500; cat. no. SA00001-2; ProteinTech Group, Inc.) at $37^{\circ} \mathrm{C}$ for $60 \mathrm{~min}$. ECL luminescent reagent was used for visualization and fixation. QuantityOne software was used to analyze the strip after film scanning. Protein relative expression level was calculated as: band gray value/internal parameter gray value. Western blot detection kit was purchased from Beyotime Institute of Biotechnology.

MTT proliferation in vitro. U87 brain glioma stem cells were prepared into a single cell suspension of $4 \times 10^{6} / \mathrm{ml}$, performed routine vaccination, and cultured in 96-well cell culture plate. Then, $20 \mu 1$ MTT solution $(5 \mathrm{mg} / \mathrm{ml})$ was added after $6 \mathrm{~h}$, and cells were cultured at $37^{\circ} \mathrm{C}$ for $4 \mathrm{~h}$ continuously. Supernatant containing impurities was removed, dimethylsulfoxide was added, and the plate was placed on a horizontal vibration table. The absorbance values at wavelength $570 \mathrm{~nm}$ were measured at 12, 24, 48 and $72 \mathrm{~h}$. The MTT test kit was purchased from Shanghai LMAI Bioengineering Co., Ltd.

Detection of differentiation of U87 brain glioma stem cells by immunomagnetic beads. U87 brain glioma stem cells were prepared into a single cell suspension of $1 \times 10^{6} / \mathrm{ml}$. CD133 cells were separated by immunomagnetic beads, washed, re-suspended, counted in serum-free medium, and the cell morphology was observed. The immunomagnetic beads kit was purchased from Shanghai Chem Biotechnology Co., Ltd.

Statistical analysis. SPSS19.0 [AsiaAnalytics (formerly SPSS China)] was used for statistical analysis. Measurement data were expressed as mean \pm standard deviation. ANOVA and the LSD post hoc test were used for multigroup comparison. The t-test was used for comparison between two groups and $\chi^{2}$ test was used for rate comparison. The correlation between miR-124 and Nogo-A, and NgR protein expression was analyzed by Spearman's correlation analysis. $\mathrm{P}<0.05$ was considered to indicate a statistically significant difference. 
Table I. Primer sequences.

\begin{tabular}{lll} 
Gene name & \multicolumn{1}{c}{ Forward primer } & Reverse primer \\
\hline miR-124 & 5'-GCTAAGGCACGCGGTG-3' & 5'-GTGCAGGGTCCGAGGT-3' \\
GAPDH & 5'-CGGAGTCAACGGATTTGGTCGTAT-3' & 5'-AGCCTTCTCCATGGTGGTGAAGAC-3'
\end{tabular}

Table II. Expression of Nogo-A and NgR protein in U87 brain glioma stem cells.

\begin{tabular}{lcc}
\hline Item & Nogo-A protein & NgR protein \\
\hline miR-124 mimic & $0.392 \pm 0.011$ & $0.533 \pm 0.012$ \\
miR-124 inhibitor & $0.569 \pm 0.013^{\mathrm{a}}$ & $0.711 \pm 0.014^{\mathrm{a}}$ \\
miR-control & $0.483 \pm 0.012^{\mathrm{a}, \mathrm{b}}$ & $0.601 \pm 0.014^{\mathrm{a}, \mathrm{b}}$ \\
$\mathrm{F}$ & 162.463 & 135.470 \\
P-value & $<0.05$ & $<0.05$ \\
\hline
\end{tabular}

${ }^{\mathrm{a} C o m p a r e d ~ w i t h ~ m i R-124 ~ m i m i c ~ g r o u p, ~} \mathrm{P}<0.05$; ${ }^{\mathrm{b}}$ Compared with miR-124 inhibitor group, $\mathrm{P}<0.05$.

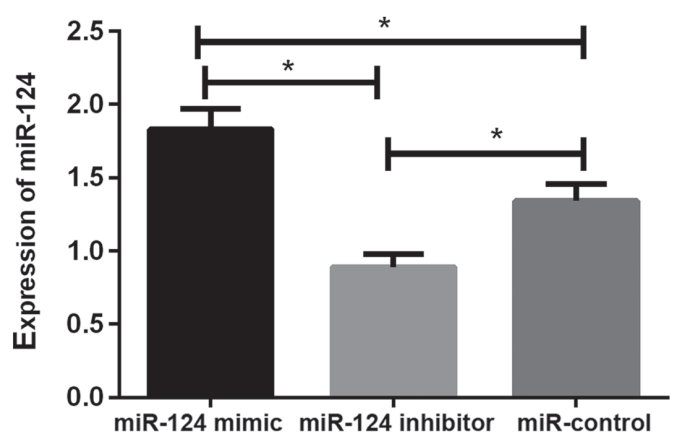

Figure 1. Relative expression of miR-124 in U87 brain glioma stem cells after transfection. The RT-qPCR results showed that the relative expression of miR-124 in cells of miR-124 mimic group was significantly higher than that of miR-124 inhibitor and miR-control groups, while miR-124 inhibitor group was lower than miR-control group. ${ }^{*} \mathrm{P}<0.05$.

\section{Results}

Relative expression of miR-124 in U87 brain glioma stem cells after transfection. The relative expression levels of miR-124 in the miR-124 mimic, miR-124 inhibitor and miR-control groups were $1.83 \pm 0.14,0.89 \pm 0.09$ and $1.34 \pm 0.12$, respectively. There was statistical difference between the three groups $(\mathrm{P}<0.05)$. The relative expression of miR-124 in cells of miR-124 mimic group was significantly higher than that of miR-124 inhibitor and miR-control groups $(\mathrm{P}<0.05)$, while the relative expression of miR-124 in cells of miR-124 inhibitor group was lower than that of miR-control group $(\mathrm{P}<0.05$; Fig. 1$)$.

Expression of Nogo-A and NgR protein in U87 brain glioma stem cells after transfection. The relative expression levels of Nogo-A protein in the miR-124 mimic, miR-124 inhibitor and miR-control groups were $0.392 \pm 0.011,0.569 \pm 0.013$ and $0.483 \pm 0.012$, respectively, the relative expression levels of $\mathrm{NgR}$ protein was $0.533 \pm 0.012,0.711 \pm 0.014$ and $0.601 \pm 0.014$,
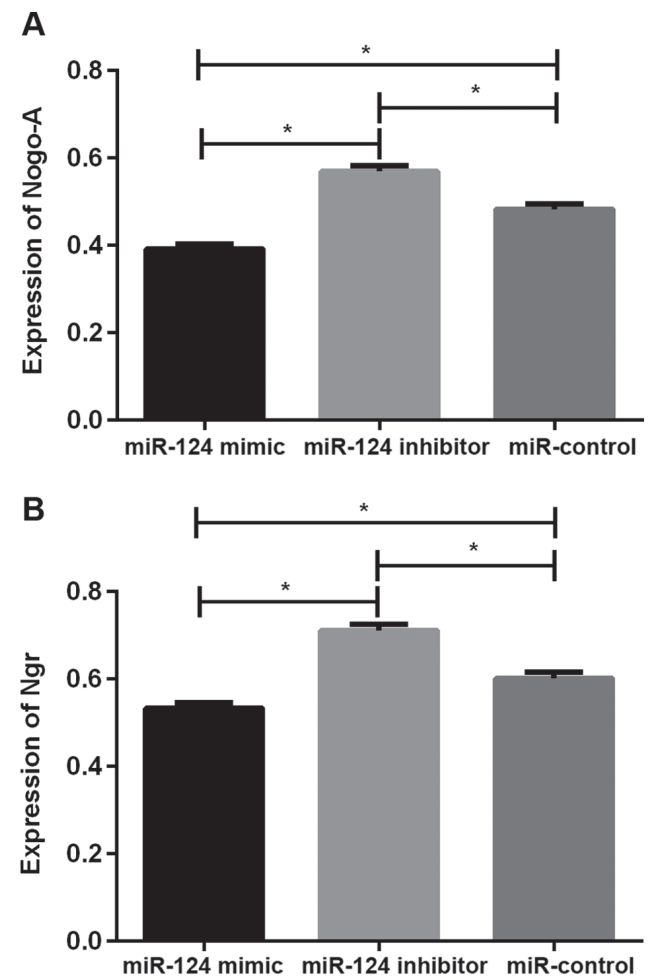

Figure 2. (A) Expressions level of Nogo-A protein in U87 brain glioma stem cells after transfection. The relative expression of Nogo-A protein in cells of miR-124 mimic group was significantly lower than that of miR-124 inhibitor and miR-control groups, while the miR-124 inhibitor group was higher than miR-control group. (B) Expression level of $\mathrm{NgR}$ protein in U87 brain glioma stem cells after transfection. The relative expression of $\mathrm{NgR}$ protein in cells of miR-124 mimic group was significantly lower than that of miR-124 inhibitor and miR-control groups, while the miR-124 inhibitor group was higher than miR-control group. ${ }^{*} \mathrm{P}<0.05$.

respectively. There was significant difference in Nogo-A and $\mathrm{NgR}$ protein between the three groups $(\mathrm{P}<0.05)$, the relative expression of Nogo-A and NgR protein in cells of miR-124 mimic group were significantly lower than those of miR-124 inhibitor and miR-control groups $(\mathrm{P}<0.05)$, while the relative expression of Nogo-A and $\mathrm{NgR}$ protein in cells of miR-124 inhibitor group were higher than those of miR-control group $(\mathrm{P}<0.05$; Table II and Fig. 2).

Detection results of U87 brain glioma stem cells by MTT proliferation in vitro. The results of MTT proliferation in vitro showed that the absorbance values in the three groups were significantly different at each time point $(\mathrm{P}<0.05)$. The absorbance values of the cells in the miR-124 mimic and miR-control groups were significantly lower than those in the miR-124 inhibitor group at each time point $(\mathrm{P}<0.05)$, while the values of the cells in the miR-124 mimic group was significantly lower than that in miR-control group ( $\mathrm{P}<0.05$; Fig. 3$)$. 


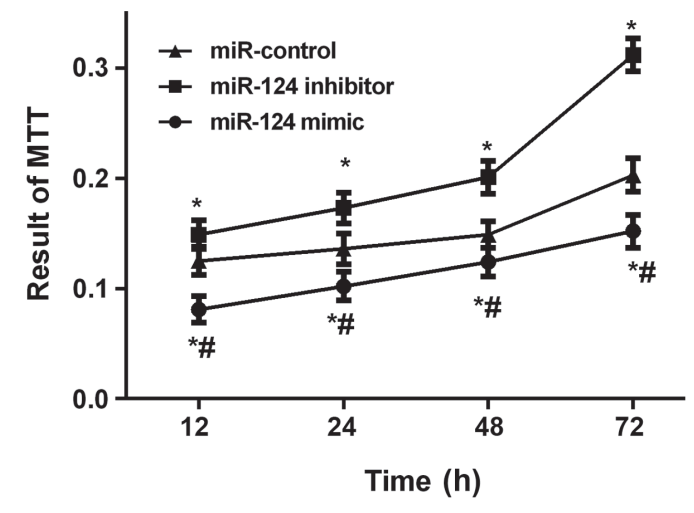

Figure 3. Detection results of U87 brain glioma stem cells by MTT proliferation in vitro. The absorbance values of the cells in the miR-124 mimic and miR-control groups were significantly lower than those in the miR-124 inhibitor group at each time point, while the miR-124 mimic group was significantly lower than miR-control group. ${ }^{*} \mathrm{P}<0.05$, compared with miR-control group; ${ }^{*} \mathrm{P}<0.05$, compared with miR-124 inhibitor group.

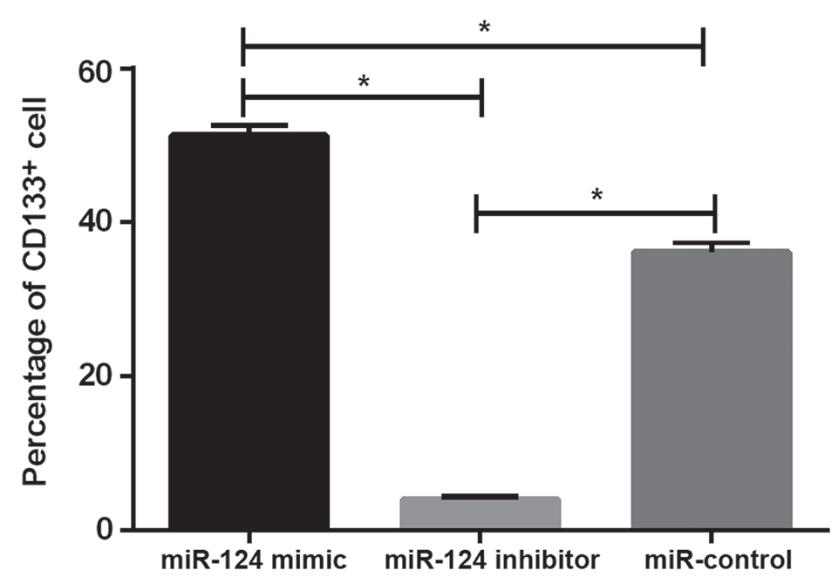

Figure 4. Detection results of $\mathrm{CD} 133^{+} \mathrm{U} 87$ brain glioma stem cells. The level of $\mathrm{CD} 133^{+}$cells in miR-124 mimic group was significantly lower than that in miR-124 inhibitor and miR-control groups, while the miR-124 inhibitor group was higher than miR-control group. ${ }^{*} \mathrm{P}<0.05$.

Detection results of $\mathrm{CD} 133^{+} \mathrm{U} 87$ brain glioma stem cells. The levels of $\mathrm{CD} 133^{+}$cells in the miR-124 mimic, miR-124 inhibitor and miR-control groups were $3.98 \pm 0.45,36.12 \pm 1.34$ and $51.25 \pm 1.48 \%$, respectively. There was statistical difference between the three groups $(\mathrm{P}<0.05)$, the level of $\mathrm{CD} 133^{+}$cells in miR-124 mimic group was significantly lower than that in miR-124 inhibitor and miR-control groups $(\mathrm{P}<0.05)$, while the level of $\mathrm{CD}_{133^{+}}$cells in miR-124 inhibitor group was higher than that in miR-control group ( $\mathrm{P}<0.05$; Fig. 4).

Correlation analysis. The results of correlation analysis showed that there was a negative correlation between miR-124 and the expression of Nogo-A ( $\mathrm{r}=-0.855,95 \%$ CI: -0.9908 to $-0.7954, \mathrm{P}<0.001)$ and $\mathrm{NgR}(\mathrm{r}=0825,95 \% \mathrm{CI}:-0.9845$ to $-0.6776, \mathrm{P}<0.001$; Fig. 5).

\section{Discussion}

With the development of molecular biology and related treatments, an increasing number of scholars have paid attention to the role of miRNA in tumors. miR-124 plays an important role
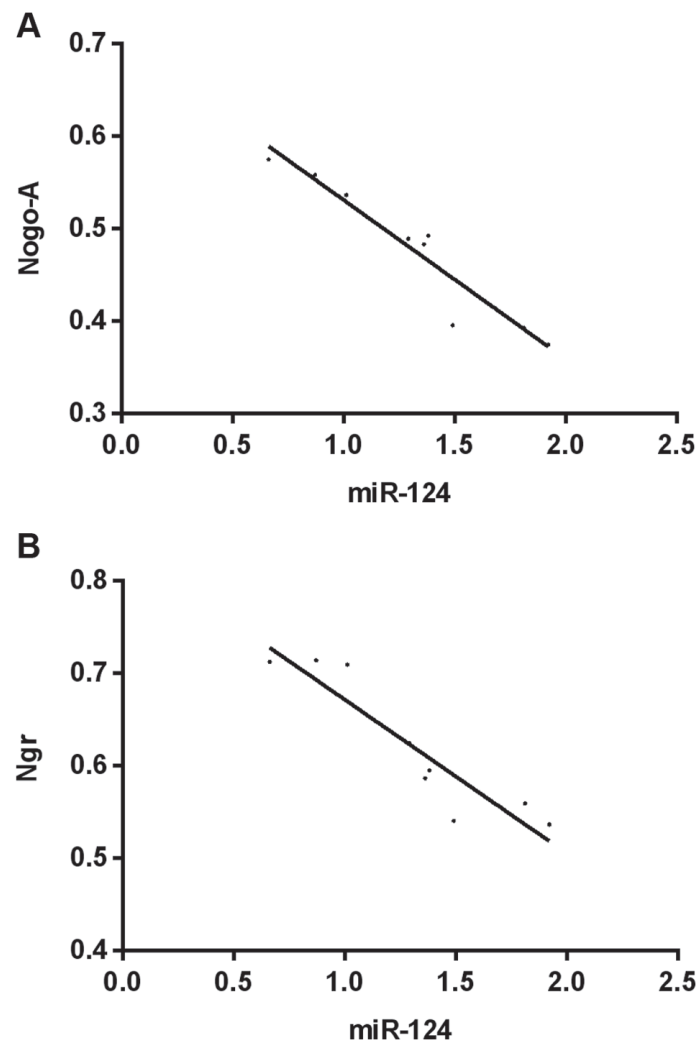

Figure 5. (A) Correlation between miR-124 and Nogo-A protein expression level. $\mathrm{r}=-0.855,95 \% \mathrm{CI}$ : -0.9908 to $-0.7954, \mathrm{P}<0.001$; (B) Correlation between miR-124 and NgR protein expression level. $r=0825,95 \%$ CI: -0.9845 to $-0.6776, \mathrm{P}<0.001$.

in neural development, but is rarely reported in gliomas. Some studies have found that the downregulation and upregulation of miR-124 expression in brain glioma can play the role of tumor suppressor gene (10), but the mechanism of miR-124 is not fully understood yet. There have been few reports on the Nogo/NgR pathway, reporting that reducing Nogo-A expression can protect brain damage and promote neuronal regeneration $(11,12)$, while brain gliomas develop from carcinogenesis of spinal cord neurons (13). Therefore, whether the Nogo/NgR pathway plays a role in brain glioma and whether it is a target for miR-124 in the differentiation of brain glioma stem cells were investigated in this study in order to provide a new direction for clinical treatment.

U87 brain glioma cells were used for screening of brain glioma stem cells because of their ability to grow into spheres, which can be used to screen stem cells that meet the experimental needs $(14,15)$. Then the overexpression vector (miR-124 mimic), underexpression vector (miR-124 inhibitor) and blank vector (miR-control) of miR-124 were constructed to transfect U87 brain glioma stem cells and to regulate the expression level of miR-124. The RT-qPCR results showed that the relative expression of miR-124 in cells of miR-124 mimic group was significantly higher than that of miR-124 inhibitor and miR-control groups, while the relative expression of miR-124 in cells of miR-124 inhibitor group was lower than that of miR-control group, which indicated that the transfection was successful. Then the expression levels of Nogo, and $\mathrm{NgR}$ protein were detected and found that with the increase of miR-124 expression level, the expression level of $\mathrm{NgR}$ protein decreased, 
and correlation analysis also revealed that there was a negative correlation between miR-124 and the expression level of Nogo and NgR protein, which suggested that there might be some regulatory relationship between miR-124 and Nogo/ NgR pathway. CD133 is recognized as a surface marker of tumor stem cells, which is not expressed on the surface of differentiated tumor cells (16). Therefore, expressing the quantitative proportion of CD133 cells can reflect the differentiation of stem cells to some extent. Analytic results of the proliferation of U87 brain glioma stem cells showed that cells with high miR-124 expression level had a low proliferative ability. The analytic results of the differentiation of U87 brain glioma stem cells showed that U87 brain glioma stem cells with high miR-124 expression had a low proportion of $\mathrm{CD} 133^{+}$cells, indicating a high degree of the differentiation. These results are similar to those reported in related studies: $\mathrm{miR}-124$ can promote the differentiation of brain glioma stem cells $(6,10)$.

Brain glioma stem cells, a special subgroup of cells, are the source of brain glioma formation with a potential to differentiate into brain glioma cells (17). Differentiation is also an important feature of brain glioma stem cells and brain glioma cells. Brain glioma stem cells have no tumorigenic ability and their infinite proliferative ability also becomes limited after differentiation into brain glioma cells $(18,19)$. Therefore, promoting the differentiation of brain glioma stem cells is also an important method for the treatment of brain glioma. On the other hand, brain glioma stem cells are more tolerant than brain glioma cells in the face of radiotherapy and chemotherapy, and their DNA repair ability is also stronger than that of brain glioma cells. Therefore, brain glioma stem cells are a new research direction in the treatment of brain glioma (20). At present this kind of treatment is still in the exploratory stage. miR-124 was first reported to participate in the differentiation of glioma stem cells in 2008, it was found that increased expression of miR-124 promoted the differentiation of brain glioma stem cells (6), but there are few reports on miR-124 and brain glioma stem cell differentiation since then. It has been reported that miR-124 can regulate the differentiation of astrocytes and other nerve cells (21). The finding verified the regulation effect of miR-124 on the differentiation of brain glioma stem cells to some extent. Nogo-A has been reported to inhibit the invasion and migration of brain glioma cells (22). Consequently, there is a close relationship between Nogo, NgR and tumor formation. The above results also improve the credibility of our conclusions to some extent.

However, this study also has some shortcomings. Brain gliomas are diverse (23). In addition, U87 brain glioma cells are only one of these subtypes; thus, the establishment of a study in other gliomas is needed for further verification. Furthermore, in vitro experiments cannot simulate the complex tumor microenvironment in vivo. Therefore, we hope that this study can promote further research in this field.

In conclusion, miR-124 may participate in the differentiation of brain glioma stem cells through the Nogo/ $\mathrm{NgR}$ pathway, which may bring a new direction for the clinical treatment of brain glioma.

\section{Acknowledgements}

Not applicable.

\section{Funding}

No funding was received.

\section{Availability of data and materials}

The datasets used and/or analyzed during the current study are available from the corresponding author on reasonable request.

\section{Authors' contributions}

YM was responsible for construction and transfection of miR-124 expression vector and PCR, as well as for drafting the manuscript. FS and YZ helped with western blot and MTT assay. All authors read and approved the final manuscript.

\section{Ethics approval and consent to participate}

This study was approved by the Ethics Committee of Xiangyang Central Hospital, Affiliated Hospital of Hubei University of Art and Science (Xiangyang, China).

\section{Patient consent for publication}

Not applicable.

\section{Competing interests}

The authors declare that they have no competing interests.

\section{References}

1. Eckel-Passow JE, Lachance DH, Molinaro AM, Walsh KM, Decker PA, Sicotte H, Pekmezci M, Rice T, Kosel ML, Smirnov IV, et al: Glioma groups based on 1p/19q, IDH, and TERT promoter mutations in tumors. N Engl J Med 372: 2499-2508, 2015.

2. Ceccarelli M, Barthel FP, Malta TM, Sabedot TS, Salama SR, Murray BA, Morozova O, Newton Y, Radenbaugh A, Pagnotta SM, et al; TCGA Research Network: Molecular profiling reveals biologically discrete subsets and pathways of progression in diffuse glioma. Cell 164: 550-563, 2016.

3. Buckner JC, Shaw EG, Pugh SL, Chakravarti A, Gilbert MR, Barger GR, Coons S, Ricci P, Bullard D, Brown PD, et al: Radiation plus procarbazine, CCNU, and vincristine in low-grade glioma. N Engl J Med 374: 1344-1355, 2016.

4. Johnson BE, Mazor T, Hong C, Barnes M, Aihara K, McLean CY, Fouse SD, Yamamoto S, Ueda H, Tatsuno K, et al: Mutational analysis reveals the origin and therapy-driven evolution of recurrent glioma. Science 343: 189-193, 2014.

5. Mantia C, Uhlmann EJ, Puligandla M, Weber GM, Neuberg D and Zwicker JI: Predicting the higher rate of intracranial hemorrhage in glioma patients receiving therapeutic enoxaparin. Blood 129: 3379-3385, 2017.

6. Silber J, Lim DA, Petritsch C, Persson AI, Maunakea AK, Yu M, Vandenberg SR, Ginzinger DG, James CD, Costello JF, et al: miR-124 and miR-137 inhibit proliferation of glioblastoma multiforme cells and induce differentiation of brain tumor stem cells. BMC Med 6: 14, 2008.

7. Fang Y, Yan J,Li C, Zhou X, Yao L, Pang T, Yan M,Zhang L, Mao L and Liao H: The Nogo/Nogo receptor $(\mathrm{NgR})$ signal is involved in neuroinflammation through the regulation of microglial inflammatory activation. J Biol Chem 290: 28901-28914, 2015.

8. Fang Y, Wang J, Yao L, Li C, Wang J, Liu Y, Tao X, Sun H and Liao $\mathrm{H}$ : The adhesion and migration of microglia to $\beta$-amyloid $(\mathrm{A} \beta)$ is decreased with aging and inhibited by $\mathrm{Nogo} / \mathrm{NgR}$ pathway. J Neuroinflammation 15: 210, 2018.

9. Livak KJ and Scmittgen TD: Analysis of relative gene expression data using real-time quantitative PCR and the 2(-Delta Delta C(T)) method. Methods 25: 402-408, 2001. 
10. Xia H, Cheung WK, Ng SS, Jiang X, Jiang S, Sze J, Leung GK Lu G, Chan DT, Bian XW, et al: Loss of brain-enriched miR-124 microRNA enhances stem-like traits and invasiveness of glioma cells. J Biol Chem 287: 9962-9971, 2012.

11. Li Q, Cheng Y, Bi MJ, Kang H, Qu Y, Lin H, Guo Y and Zou Y: Effects of N-Butylphthalide on the expressions of $\mathrm{Nogo} / \mathrm{NgR}$ in rat brain tissue after carbon monoxide poisoning. Environ Toxicol Pharmacol 39: 953-961, 2015.

12. Buchli AD and Schwab ME: Inhibition of Nogo: a key strategy to increase regeneration, plasticity and functional recovery of the lesioned central nervous system. Ann Med 37: 556-567, 2005.

13. Hambardzumyan D, Gutmann DH and Kettenmann H: The role of microglia and macrophages in glioma maintenance and progression. Nat Neurosci 19: 20-27, 2016.

14. Liu Y, Zhang B, Wen C, Wen G, Zhou G, Zhang J, He H, Wang N and $\mathrm{Li} \mathrm{W}$ : Overexpressed miRNA-134b inhibits proliferation and invasion of $\mathrm{CD}_{133^{+}} \mathrm{U} 87$ glioma stem cells. Xi Bao Yu Fen Zi Mian Yi Xue Za Zhi 33: 637-642, 2017 (In Chinese).

15. Guo Y, Zhang P, Zhang H, Zhang $\mathrm{P}$ and Xu R: RNAi for contactin 2 inhibits proliferation of U87-glioma stem cells by downregulating AICD, EGFR, and HES1. OncoTargets Ther 10: 791-801, 2017.

16. Cervantes-Madrid D, Wettergren Y, Falk P, Lundholm K and Asting AG: DNA alterations in $\mathrm{Cd}_{133^{+}}$and $\mathrm{Cd} 133^{-}$tumour cells enriched from intra-operative human colon tumour biopsies BMC Cancer 17: 219, 2017.

17. Kim SH, Ezhilarasan R, Phillips E, Gallego-Perez D, Sparks A, Taylor D, Ladner K, Furuta T, Sabit H, Chhipa R, et al: Serine/threonine kinase MLK4 determines mesenchymal identity in glioma stem cells in an NF- $\mathrm{BB}$-dependent manner. Cancer Cell 29: 201-213, 2016.

18. Kim SH, Joshi K, Ezhilarasan R, Myers TR, Siu J, Gu C, Nakano-Okuno M, Taylor D, Minata M, Sulman EP, et al: EZH2 protects glioma stem cells from radiation-induced cell death in a MELK/FOXM1-dependent manner. Stem Cell Rep 4: 226-238, 2015 .
19. Miao H, Gale NW, Guo H, Qian J, Petty A, Kaspar J, Murphy AJ, Valenzuela DM, Yancopoulos G, Hambardzumyan D, et al: EphA2 promotes infiltrative invasion of glioma stem cells in vivo through cross-talk with Akt and regulates stem cell properties. Oncogene 34: 558-567, 2015.

20. Neo WH, Yap K, Lee SH, Looi LS, Khandelia P, Neo SX, Makeyev EV and Su IH: MicroRNA miR-124 controls the choice between neuronal and astrocyte differentiation by fine-tuning Ezh2 expression. J Biol Chem 289: 20788-20801, 2014.

21. Santos MC, Tegge AN, Correa BR, Mahesula S, Kohnke LQ, Qiao M, Ferreira MA, Kokovay E and Penalva LO: miR-124, -128 , and -137 orchestrate neural differentiation by acting on overlapping gene sets containing a highly connected transcription factor network. Stem Cells 34: 220-232, 2016.

22. Cantalupo A, Zhang Y, Kothiya M, Galvani S, Obinata $H$, Bucci M, Giordano FJ, Jiang XC, Hla T and Di Lorenzo A: Nogo-B regulates endothelial sphingolipid homeostasis to control vascular function and blood pressure. Nat Med 21: 1028-1037, 2015.

23. Jin SG, Ryu HH, Li SY, Li CH, Lim SH, Jang WY and Jung S: Nogo-A inhibits the migration and invasion of human malignant glioma U87MG cells. Oncol Rep 35: 3395-3402, 2016.

(i)(5) This work is licensed under a Creative Commons Attribution-NonCommercial-NoDerivatives 4.0 International (CC BY-NC-ND 4.0) License. 